\title{
Pengaruh Pelatihan Caring Terhadap Perilaku Memberikan Asuhan Keperawatan pada Mahasiswa Saat Rotasi Klinik di Politeknik Depkes Palangka Raya
}

\author{
Maria Magdalena Purba*, Ova Emilia**, Gandes Retno Rahayu** \\ * Politeknik Depkes Palangka Raya \\ ** Fakultas Kedokteran Universitas Gadjah Mada, Yogyakarta
}

\begin{abstract}
Background: Caring in nursing is a very basic component, as the heart of profession, Which means that caring is a fundamental component, and central and unique focus of nursing. Caring, which is a core of nursing practice, must grow from self and deepest heart to help other people since being a nursing student so that caring in nursing education, must be placed as main competency in nursing education.

Aim: The aim of this research to evaluation the efficacy of caring training in improving understand cognitive, affective and psychomotor competencies of caring, among students during clinical period

Method: This research used quasi experiment non-randomized control group pretest-posttest design. Respondents of research were nursing students of Poltekes Palangka Raya, Semester $V$, regular class, X-A period, with total of 37 respondents as intervention group and regular class of X-B period with total of 35 respondents as control group.

Results and Discussion: Data were analyzed using descriptive and inferential statistical analyses. Results of research indicated that cognitive, affective and psychomotor competencies of caring in nursing students with caring training did not show significant effect (cognitive: p-value $=0,21$, affective: p-value $=0.58$, psychomotor: p-value $=0.07$ ); however, the average scores were higher among student received caring training The caring behavior showed no difference between male and female students.
\end{abstract}

Conclusion: There is insignificant difference between students with caring training and students without caring training. The training should be modified as suggested in the paper.

Keywords: caring, caring behavior, clinical practice of nursing, clinical shift.

\begin{abstract}
Abstrak
Latar Belakang: Caring dalam keperawatan adalah hal yang sangat mendasar, caring merupakan jantung profesi, artinya sebagai komponen yang fundamental dan fokus sentral serta unik dari keperawatan. Caring yang merupakan inti dari praktik keperawatan harus tumbuh dari dalam diri dan berasal dari hati yang paling dalam untuk menolong orang lain sejak menjadi mahasiswa keperawatan sehingga caring dalam asuhan keperawatan harus dijadikan sebagai kompetensi dalam pendidikan keperawatan.

Tujuan: Penelitian ini bertujuan untuk mengetahui pengaruh pelatihan caring terhadap kemampuan kognitif, kemampuan afektif dan kemampuan psikomotor caring dalam memberikan asuhan keperawatan pada mahasiswa saat rotasi klinik.

Metode: Penelitian ini menggunakan metode quasi experimental non-randomized control group pretest-postest design. Responden penelitian adalah mahasiswa keperawatan Poltekes Palangka Raya semester V kelas reguler angkatan $\mathrm{X}$-A yang berjumlah 37 orang sebagai kelompok intervensi dan kelas reguler angkatan X-B yang berjumlah 35 orang sebagai kelompok control.

Hasil dan Pembahasan: Data dianalis dengan menggunakan analisis statistik deskriptif dan analisis statistik inferensial. Hasil penelitian menunjukkan bahwa kemampuan kognitif, kemampuan afektif dan kemampuan psikomotor caring dalam asuhan keperawatan antara mahasiswa yang diberi pelatihan caring dengan mahasiswa
\end{abstract}

Korespondensi: magdadasuha@yahoo.co.id 
yang tidak diberi pelatihan caring secara statistik tidak menunjukkan pengaruh yang bermakna, (kognitif: $p$ value $=0,21$, afektif: $p$-value $=0,58$, psikomotor: $p$-value $=0,07)$. Namun bila ditinjau berdasarkan hasil dari nilai rata-rata, maka hasil nilai rata-rata mahasiswa yang diberi pelatihan caring lebih tinggi dari pada nilai rata-rata mahasiswa yang tidak diberi pelatihan caring. Tidak terdapat perbedaan perilaku caring dalam memberikan asuhan keperawatan pada mahasiswa yang berjenis kelamin laki-laki.

Kesimpulan: Terdapat pengaruh yang tidak bermakna antara mahasiswa yang diberi pelatihan caring dengan mahasiswa yang tidak diberi pelatihan caring dalam asuhan keperawatan. Pelatihan perlu dimodifikasi sesuai ranah dalam makalah.

Kata Kunci: caring, perilaku caring, praktek klinik keperawatan, rotasi klinik.

\section{PENDAHULUAN}

Caring dalam keperawatan menurut Kozier \& Erb's ${ }^{1}$ adalah hal yang sangat mendasar, caring merupakan jantung profesi, artinya sebagai komponen yang fundamental dan unik dari keperawatan. Caring mengandung tiga hal yang tidak dapat dipisahkan yaitu perhatian, tanggung jawab dan dilakukan dengan ikhlas, caring dapat ditunjukkan melalui tingkah laku seperti: menjadi pendengar yang baik bagi klien, menaruh perhatian kepada klien, menghargai klien dengan menunjukkan komitmennya untuk mengerti, menerima klien dan meningkatkan kemampuan klien untuk bertanggung jawab atas dirinya sehingga identitas diri klien meningkat. Sikap perawat yang caring akan membantu klien untuk mengerti masalah yang dihadapinya, sehingga penempatan perilaku caring sebagai dasar dalam praktek keperawatan merupakan fokus utama yang harus dilakukan dalam asuhan keperawatan.

Pendekatan caring yang diharapkan dalam memberikan asuhan keperawatan adalah perilaku caring perawat yang didasari oleh teori Watson yang dipublikasikan pada tahun 1979 yaitu The Philosophy and Science of Caringyang dikenal dengan faktor-faktor karatif (carative factors), teori ini dikembangkan dari perspektif humanistik dengan kombinasi dasar ilmu pengetahuan, serta diartikan sebagai pertanggungjawaban perawat kepada orang lain yaitu klien. 1,2,3,4

Perkembangan keperawatan menuntut hubungan terapeutik antara perawat dan klien, sehingga klien bukan lagi seorang penerima asuhan keperawatan pasif, klien berhak mendapat informasi yang lebih baik mengenai asuhan keperawatannya dan berhak meminta standar asuhan keperawatan yang berkualitas. Standar Asuhan Keperawatan yang berkualitas mestinya dapat diberikan oleh perawat maupun mahasiswa keperawatan yang sedang melaksanakan rotasi klinik. Bila mahasiswa keperawatan telah memahami dan menjiwai secara mendalam tentang caring dalam asuhan keperawatan, maka tidak akan ada lagi fenomena di lapangan yang mengindikasikan perawat/ mahasiswa keperawatan belum bersikap caring dalam memberikan asuhan keperawatan.

Pengamatan awal peneliti menemukan mahasiswa keperawatan Poltekkes Palangkaraya yang sedang rotasi klinik belum melakukan pengkajian/pengecekan sesering mungkin kepada klien, khususnya kepada klien yang memerlukan perawatan parsial dan perawatan total. Klien dengan perawatan parsial dan perawatan total memiliki kebutuhan dasar seperti kebersihan diri, makan, minum, eliminasi, mengatur posisi serta observasi tanda-tanda vital (nadi, suhu, pernafasan dan tekanan darah) yang harus dibantu sepenuhnya. Kondisi seperti di atas sering diabaikan oleh mahasiswa keperawatan yang sedang rotasi klinik. Mahasiswa keperawatan lebih memperhatikan dan memusatkan diri pada fenomena medik seperti cara diagnostik dan cara pengobatan. Indikasi lain yang juga menunjukkan belum optimalnya caring perawat dalam memberikan asuhan keperawatan kepada klien adalah ketidakpuasan klien terhadap mutu pelayanan kesehatan. Hal ini ditunjukkan pada penelitian Agustin ${ }^{5}$, dari 6 komponen caring yang diteliti yaitu kesiapan membantu, penjelasan dan kemudahan, kenyamanan, tindakan antisipasi, membina hubungan 
saling percaya dengan klien serta pemantauan dan pengawasan hasil penelitiannya, ternyata perawat belum sepenuhnya berperilaku caring dalam memberikan asuhan keperawatan dan tingkat kepuasan klien terhadap pelayanan keperawatan masih sangat rendah, dari 6 komponen caring yang diteliti hanya kesiapan membantu yang berhubungan secara signifikan dengan kepuasan klien. Penyebab dari ketidakpuasan klien adalah perilaku caring yang diberikan masih kurang memuaskan. $.5,5$ Caring yang merupakan inti dari praktik keperawatan harus tumbuh dari dalam diri dan berasal dari hati yang paling dalam untuk menolong sejak menjadi mahasiswa keperawatan, sehingga caring dalam asuhan keperawatan harus ditetapkan menjadi kompetensi pada pendidikan keperawatan. Tujuan penelitian adalah menilai kompetensi faktor karatif caring dalam memberikan asuhan keperawatan pada mahasiswa keperawatan Poltekkes Palangka Raya saat rotasi klinik.

\section{METODE}

Rancangan penelitian yang digunakan pada penelitian ini adalah quasi experiment non-randomized control group pretestpostest design. Mahasiswa dikelompokkan menjadi dua kelompok yaitu yang diberi pelatihan caring dalam asuhan keperawatan dan yang tidak diberi pelatihan caring dalam asuhan keperawatan. Pengaruh pelatihan caring terhadap perilaku dalam memberikan asuhan keperawatan pada mahasiswa saat rotasi klinik diukur berdasarkan kemampuan kognitif, afektif dan psikomotor caring. Alat ukur yang digunakan adalah 6 dari 10 faktor karatif caring Watson yaitu: 1) Membentuk dan menghargai sistem nilai humanistik dan altruistik, 2) Menumbuhkan sensitifitas atau kepekaan terhadap diri sendiri dan orang lain, 3) Mengembangkan hubungan saling percaya dan saling membantu, 4) Menggunakan metode sistematis dalam penyelesaian masalah caring untuk pengambilan keputusan secara kreatif dan individualistik, 5) Meningkatkan proses belajar mengajar interpersonal, 6) Membantu kebutuhan dasar manusia dengan penuh penghargaan dalam rangka mempertahankan keutuhan dan martabat manusia. ${ }^{3,7,8,9,10}$ Alat ukur untuk kemampuan kognitif dan afektif caring dalam asuhan keperawatan diadopsi dan dimodifikasi dari Nurachmah dalam Purwaningsih 3,6,11 Sedangkan alat untuk mengukur kemampuan psikomotor caring dalam asuhan keperawatan dikembangkan sendiri oleh peneliti.
Prosedur dalam penelitian ini terdiri dari dua (2) tahap yaitu tahap persiapan dan tahap pelaksanaan.

a. Tahap persiapan meliputi:

1) Mensosialisasikan dan menjelaskan tujuan penelitian,

2) Menyesuaikan jadwal pelaksanaan penelitian sesuai dengan pelaksanaan rotasi klinik yang telah ditetapkan oleh akademik,

3) Meminta kesediaan mahasiswa sebagai responden untuk uji coba instrumen kemampuan kognitif dan afektif caring dalam asuhan keperawatan. Hasil uji coba langsung dianalisis dengan uji validitas dan reliabilitas,

4) Meminta kesediaan beberapa dosen ahli. Kualifikasi dosen ahli adalah dosen yang mengampu mata kuliah inti keperawatan dan komunikasi dalam keperawatan lebih dari 3 angkatan dan pernah mengikuti pelatihan yang berkaitan dengan caring dalam asuhan keperawatan. Ada 4 orang dosen yang bersedia untuk melakukan uji validitas konstruk terhadap instrumen kemampuan psikomotor. Hasil tinjauan segera direvisi agar instrumen psikomotor dapat digunakan oleh pembimbing klinik untuk mengobservasi perilaku caring mahasiswa dalam memberikan asuhan keperawatan. Instrumen psikomotor yang telah direvisi diujicobakan kepada 4 orang pembimbing klinik untuk menyempurnakan pemahaman dari instrumen tersebut,

5) Memohon kesediaan dua orang ahli sebagai fasilitator dalam pelatihan untuk membantu peneliti,

6) Menetapkan materi pelatihan yaitu: faktor karatif caring dalam asuhan keperawatan dan komunikasi terapeutik dalam asuhan keperawatan. Metode pelatihan dilakukan dengan ceramah, tanya jawab, role play/ demonstrasi, diskusi serta rotasi klinik,

7) Menetapkan kualifikasi pembimbing klinik yang akan menjadi observer yaitu pembimbing klinik yang pendidikannya D-III keperawatan dengan masa kerja minimal 5 (lima) tahun. Alasan penetapan kriteria ini adalah untuk mengurangi bias didalam pelaksanaan observasi. 
b. Tahap pelaksanaan meliputi:

1) Melaksanakan pretest untuk mengukur kemampuan awal terhadap pengetahuan dan sikap 6 dari 10 faktor karatif caring kepada kelompok intervensi dan kelompok kontrol. Sebelum pretest dilaksanakan terlebih dahulu diberi petunjuk agar tidak ada kesalahpahaman dan keraguan dalam pengisian kuesioner,

2) Melaksanakan pelatihan pada kelompok intervensi dengan materi caring dalam asuhan keperawatan, dokumentasi dan proses keperawatan serta komunikasi terapeutik dalam asuhan keperawatan dengan metode kuliah, diskusi, tanya jawab, role play demonstrasi yang dilanjutkan dengan rotasi klinik selama dua (2) minggu. Pelatihan dilaksanakan selama 2 hari,

3) Melatih 8 orang pembimbing klinik (dua orang pembimbing klinik dari setiap ruangan yang akan digunakan untuk pelaksanaan rotasi klinik yaitu ruang NCC, ruang $\mathrm{C}$, ruang $\mathrm{D}$ dan ruang $\mathrm{F}$ ). Pembimbing klinik yang telah diberi pelatihan caring akan melakukan observasi kemampuan psikomotor caring dalam asuhan keperawatan terhadap kelompok intervensi,

4) Pelaksanaan penelitian disesuaikan dengan sasaran tujuan pembelajaran klinik pada mata ajar keperawatan anak II, keperawatan maternitas II dan keperawatan medical bedah IV, sehingga lokasi penelitian dibatasi pada empat ruangan rawat inap rumah sakit dr. Doris Sylvanus yaitu dua ruangan (ruang D dan ruang NCC) untuk mencapai tujuan pembelajaran klinik mata ajar keperawatan medikal bedah IV, ruangan $\mathrm{C}$ untuk mencapai tujuan pembelajaran klinik mata ajar keperawatan maternitas II dan ruangan F untuk mencapai tujuan pembelajaran klinik mata ajar keperawatan II

5) Pelaksanaan pos tes: pos tes dilaksanakan dengan cara melakukan observasi kemampuan caring terhadap kedua kelompok responden

\begin{abstract}
dilakukan setelah kedua kelompok mengikuti dua minggu proses pelaksanaan rotasi klinik, serta pengisian dan penyebaran kembali kuesioner kemampuan kognitif dan afektif caring dalam asuhan keperawatan kepada kedua kelompok,
\end{abstract}

Hasil pre tes dan pos tes pada penelitian ini dianalisis dengan menggunakan analisis statistik deskriptif dan analisis statistik inferensial. Analisis statistik deskriptif bertujuan untuk mengetahui nilai rata-rata, standar deviasi (SD), nilai minimum dan nilai maksimum dari variabel penelitian. Statistik inferensial bertujuan untuk menguji hipotesis penelitan. Uji hipotesis pada penelitian ini, dilakukan dengan menggunakan uji independen sampel t-tes. Uji ini dilakukan setelah melalui tahap uji homogenitas dan normalitas dengan Kolmogorov-Smimov (KS) yang terdapat dalam prosedur SPSS 15 Explore dengan hasil analisis data adalah normal dan homogen.

\section{HASIL}

Tabel 1 menunjukkan uji kesetaraan atau uji homogenitas pre tes kemampuan kognitif dan afektif antara kelompok intervensi dengan kelompok kontrol. Uji homogenitas dilakukan terhadap pre tes kemampuan kognitif dan kemampuan afektif caring dalam asuhan keperawatan antara kelompok intervensi dengan kelompok kontrol dan jenis kelamin antara kelompok intervensi dengan kelompok kontrol. Dari hasil uji homogenitas yang dilakukan hasil yang diperoleh menunjukkan bahwa nilai $p$ value $(\mathrm{p}>0,05)$, yang artinya adalah bahwa nilai data hasil pre tes kemampuan kognitif dan kemampuan afektif antara kelompok intervensi dengan kelompok kontrol memiliki varians yang homogen. Kemudian data dianalisis dengan uji independen sampel $\mathrm{T}$ tes dengan tingkat kemaknaan 95\% untuk membandingkan nilai kedua kelompok. Hasilnya menunjukkan tidak ada perbedaan yang bermakna $(p>0,05)$ antara hasil pre tes kemampuan kognitif dan hasil pre tes kemampuan afektif kelompok intervensi dengan kelompok kontrol. 
Tabel 1. Uji homogenitas pre tes kemampuan kognitif dan kemampuan afektif caring dalam asuhan keperawatan antara kelompok intervensi dengan kelompok kontrol

\begin{tabular}{|c|c|c|c|c|c|c|}
\hline Kelompok & \multicolumn{2}{|c|}{$\begin{array}{c}\text { Intervensi } \\
\mathbf{n}=37\end{array}$} & \multicolumn{2}{|c|}{$\begin{array}{c}\text { Kontrol } \\
\mathrm{n}=35\end{array}$} & \multirow{2}{*}{ t- tes } & \multirow{2}{*}{ p-value } \\
\hline Variabel & Mean & SD & mean & SD & & \\
\hline Pre tes kognitif & 12,41 & 1,48 & 12,44 & 1,38 & 0,07 & 0,95 \\
\hline Pre tes afektif & 42,51 & 2,77 & 41,40 & 3,11 & $-0,04$ & 0,97 \\
\hline Laki-laki & \multicolumn{2}{|c|}{$\mathrm{n}=20$} & \multicolumn{2}{|c|}{$\mathrm{n}=17$} & $X^{2}$ & \\
\hline & \multicolumn{2}{|c|}{$54,1 \%$} & \multicolumn{2}{|c|}{$48,6 \%$} & (Chi square) & 0,41 \\
\hline Perempuan & \multicolumn{2}{|c|}{$\mathrm{n}=17$} & \multicolumn{2}{|c|}{$\mathrm{n}=18$} & 0,22 & \\
\hline & \multicolumn{2}{|c|}{$45,9 \%$} & \multicolumn{2}{|c|}{$51,4 \%$} & & \\
\hline
\end{tabular}

Tabel 2 menunjukkan perubahan rata-rata hasil pos tes kemampuan kognitif dan kemampuan afektif kelompok intervensi dengan kelompok kontrol serta hasil observasi kemampuan psikomotor caring dalam asuhan keperawatan antara kelompok intervensi dengan kelompok kontrol. Uji perbedaan antar variabel menggunakan uji independen sampel $t$ tes.

\begin{tabular}{|c|c|c|c|c|c|c|c|}
\hline \multirow{2}{*}{\multicolumn{2}{|c|}{$\begin{array}{l}\text { Kelompok } \\
\text { Variabel }\end{array}$}} & \multicolumn{2}{|c|}{ Pre tes } & \multicolumn{2}{|c|}{ Pos tes } & \multicolumn{2}{|c|}{ Rata-rata perubahan } \\
\hline & & Mean & SD & Mean & SD & Mean & SD \\
\hline \multirow{4}{*}{ Kognitif } & Intervensi & 12,41 & 1,48 & 12,86 & 2,21 & 0,57 & 2,19 \\
\hline & Kontrol & 12,44 & 1,38 & 12,40 & 1,52 & $-0,03$ & 1,76 \\
\hline & $\mathbf{t}$ & \multirow{2}{*}{\multicolumn{2}{|c|}{$\begin{array}{l}0,07 \\
0,95\end{array}$}} & \multirow{2}{*}{\multicolumn{2}{|c|}{$\begin{array}{r}-0,21 \\
0,83\end{array}$}} & \multirow{2}{*}{\multicolumn{2}{|c|}{$\begin{array}{l}1,27 \\
0,21\end{array}$}} \\
\hline & pralue & & & & & & \\
\hline \multirow{4}{*}{ Afektif } & Intervensi & 42,51 & 2,77 & 43,41 & 3,63 & 0,89 & 4,80 \\
\hline & Kontrol & 41,40 & 3,11 & 41,80 & 3,42 & 0,40 & 2,17 \\
\hline & $t$ & \multicolumn{2}{|c|}{$-0,04$} & \multicolumn{2}{|c|}{$-1,93$} & \multicolumn{2}{|c|}{0,55} \\
\hline & p-value & \multicolumn{2}{|c|}{0,97} & \multicolumn{2}{|c|}{0,06} & \multicolumn{2}{|c|}{0,58} \\
\hline & Intervensi & & & 32,32 & 6,41 & & \\
\hline Psikomo- & Kontrol & & & 29,69 & 5,61 & & \\
\hline tor & $\mathbf{t}$ & \multicolumn{6}{|c|}{1,85} \\
\hline & p-value & \multicolumn{6}{|c|}{0,07} \\
\hline
\end{tabular}

Hasil dari Tabel 2 menunjukkan bahwa berdasarkan perubahan hasil rata-rata kemampuan kognitif, afektif dan psikomotor caring dalam asuhan keperawatan antara kelompok intervensi dengan kelompok kontrol tidak menunjukkan perubahan yang bermakna, namun didapatkan bahwa nilai rata-rata kelompok intervensi lebih tinggi dari pada nilai rata-rata kelompok kontrol.

\section{PEMBAHASAN}

Pengaruh Pelatihan Caring Terhadap Kemampuan Kognitif

Kemampuan kognitif caring dalam asuhan keperawatan diukur berdasarkan instrumen kemampuan kognitif berbentuk kuesioner dengan tipe soal MCQ dan jumlah item soal sebanyak 18 , dengan skor tiap item adalah 0 
jika salah dan 1 jika benar. Sebelum diberi pelatihan terlebih dahulu dilakukan pre tes terhadap kelompok intervensi dan kelompok kontrol dan hasilnya dianalisis, kemudian dilakukan pelatihan caring dalam asuhan keperawatan kepada kelompok intervensi. Pelatihan caring dalam asuhan keperawatan disesuaikan dengan modul yang telah dirancang oleh peneliti, adapun metode yang digunakan oleh peneliti untuk mencapai kemampuan kognitif caring dalam asuhan keperawatan pada pelatihan ini adalah metode ceramah selama 45 menit serta diskusi dan tanya jawab selama 15 menit dengan fokus materi adalah domain caring menurut Watson.

Hasil analisis penelitian terhadap kemampuan kognitif caring dalam memberikan asuhan keperawatan pada mahasiswa saat rotasi klinik antara kelompok intervensi dengan kelompok kontrol menunjukkan hasil yang tidak bermakna. Hasil dari penelitian ini diperkuat oleh pendapat Patrick (1992). Patrick mengemukakan ada tiga komponen yang mempengaruhi program pelatihan yaitu: 1) Isi pelatihan, 2) Metode dan strategi pelatihan dan 3) Karakteristik orang yang dilatih. ${ }^{10}$ Berdasarkan yang dikemukakan oleh Patrick menunjukkan bahwa kelompok yang diberi pelatihan caring pada penelitian ini kurang menguasai isi program pelatihan yang diberikan. Ada beberapa hal yang dapat mempengaruhi tidak bermaknanya hasil dari suatu pelatihan antara lain yaitu: kurangnya penguasaan peserta pelatihan terhadap isi program pelatihan yang diberikan, hal ini dapat terjadi karena kurangnya keinginan dari peserta pelatihan untuk mengulang kembali atau mempelajari kembali isi program pelatihan yang telah diberikan. Hal ini didukung oleh pendapat dari Emilia ${ }^{12}$ dalam artikelnya tentang tips meningkatkan retensi memori, yang menyatakan sering mengulang informasi atau mengulang apa yang telah dipelajari pada hari yang sama dengan interval tertentu akan dapat membuat retensi informasi menjadi lebih baik. Menurut Irwanto $\mathrm{dkk}^{13}$ interval atau jarak waktu antara memasukkan informasi dengan memunculkan kembali informasi tersebut merupakan hal yang harus diperhatikan. Lamanya interval menunjukkan tentang lamanya waktu antara pemasukan informasi (act of learning) sampai dimunculkannya kembali informasi tersebut. Lama interval berkaitan dengan kekuatan retensi. Makin lama interval, makin kurang kuat retensi, atau kekuatan retensinya menurun. Banyaknya isi interval berkorelasi negatif dengan retensi, artinya semakin banyak isi interval maka semakin lemah retensi individu. Aktivitas-aktivitas yang mengisi interval akan merusak atau mengganggu jejak ingatan sehingga individu akan mengalami kelupaan. Kemampuan untuk menerima (encoding), menyimpan (storage) dan menimbulkan kembali informasi yang telah diterima (retrieval) dipengaruhi oleh memori jangka pendek dan memori jangka panjang. ${ }^{14}$ Proses penyimpanan informasi didalam memori jangka pendek relatif singkat, yaitu lebih kurang 20 menit, sehingga perlu dilakukan latihan dan pengulangan secara kontinyu atau dengan cara melakukan elaborasi dengan cara mengasosiasikan hal-hal yang akan dilatihkan kepada peserta pelatihan..$^{14}$

Kemampuan kognitif caring mahasiswa diukur berdasarkan teori caring Watson yaitu 6 dari 10 faktor karatif caring yang mana topik atau materi pelatihan tersebut merupakan suatu model konseptual. Belajar terhadap suatu konsep harus sering diulang oleh si pembelajar agar informasi tentang konsep yang dipelajari tersebut dapat tersimpan didalam memori dan jika ada stimulus maka informasi yang tersimpan tersebut dapat diorganisasikan melalui respon. ${ }^{15}$

Poin ke dua dari komponen yang dikemukan oleh Patrick adalah metode dan strategi pelatihan caring yang dilakukan. ${ }^{10}$ Bila ditinjau berdasarkan teori piramida belajar, metode pelatihan yang dilakukan oleh peneliti masih menunjukkan metode pelatihan atau pengajaran yang pasif dan hanya mampu menyerap informasi sebesar $5 \%$ sedangkan untuk metode demonstrasi mampu menyerap retensi sebesar 30\%. Sehingga teori piramida belajar juga merupakan alasan yang memperkuat mengapa hasil dari penelitian pengaruh pelatihan caring terhadap perilaku mahasiswa dalam memberikan asuhan keperawatan tidak menunjukkan hasil yang bermakna. Sedangkan point ke 3 dari komponen pelatihan menurut Patrick adalah karateristik orang yang dilatih. Karakteristik ini meliputi pengetahuan peserta yang dilatih, usia, tingkat kecerdasan serta motivasi dan tingkah laku. Bila dilihat berdasarkan karakteristik orang yang dilatih maka peserta pelatihan berada pada tingkat kecerdasan yang sama. 


\section{Pengaruh Pelatihan Caring Terhadap Kemampuan Psikomotor}

Hasil analisis terhadap kemampuan psikomotor antara kelompok intervensi dengan kelompok kontrol juga menunjukkan hasil yang tidak bermakna. Hal ini didukung oleh pendapat Dave dalam Arends R.I ${ }^{15}$ yang mengatakan bahwa hasil belajar atau pelatihan psikomotor dapat dibedakan menjadi lima tahap, yaitu: imitasi, manipulasi, presisi, artikulasi, dan naturalisasi. ${ }^{15}$ Artinya perlu waktu dan pengulangan untuk menguasi suatu keterampilan. Hal ini sejalan dengan Goetz ${ }^{16}$ dalam penelitiannya bahwa latihan yang dilakukan berulangulang akan memberikan pengaruh yang sangat besar pada kemahiran keterampilan. Lebih lanjut dalam penelitian itu dilaporkan bahwa pengulangan saja tidak cukup menghasilkan prestasi belajar yang tinggi, namun diperlukan umpan balik yang relevan yang berfungsi untuk memantapkan kebiasaan. Semenara itu Bond \& Spurritt ${ }^{17}$ mengemukakan ada empat hal yang spesifik yang perlu diperhatikan ketika mengajarkan keterampilan yaitu: fase kognitif, fase tertutup, fase terbuka dan fase otomatis. Fase kognitif adalah fase dimana si pembelajar belum mengetahui tentang isi dan cakupan suatu topik keterampilan, kemudian si pembelajar akan menjadi paham tentang isi dan topik serta bagaimana melakukan praktek keterampilan itu. Fase tertutup adalah fase dimana si pembelajar sudah mengetahui apa yang harus dilakukan, bagaimana melakukan keterampilan itu, dan telah mencoba mempraktekkan keterampilan tersebut, walau dengan berbagai kekurangan atau ketidaksempurnaan. Fase terbuka adalah fase dimana si pembelajar mampu melakukan praktek keterampilan sesuai dengan prosedur yang benar dan fase otomatis adalah melakukan dengan benar dan konsisten pada fase ini si pembelajar sudah dapat melakukan praktek keterampilan tersebut dengan benar, konsisten dan secara otomatis. Mahasiswa baru dapat dikatakan mahir melakukan pratek keterampilan apabila telah mampu melakukan praktek keterampilan dengan benar, konsisten dalam berbagai setting situasi. Pada setiap praktek keterampilan agar si pembelajar dapat meningkatkan keterampilannya pada fase diatasnya sangat diperlukan feedback dan refleksi untuk memperbaiki dan menyempurnakan keterampilan tersebut. Dari literatur tersebut diatas, maka tidak bemaknanya hasil analisis terhadap kemampuan psikomotor pada kedua kelompok adalah karena kurangnya waktu pelatihan tidak dilakukan secara berulang-ulang, dan tidak ada feedback dari pembimbing klinik terhadap keterampilan caring yang telah dilakukan oleh mahasiswa.

Fakta lain yang mendukung hasil dalam penelitian ini juga dipengaruhi oleh tingkat kesulitan untuk melakukan keterampilan caring dalam asuhan keperawatan. Menurut Guadagnoli \& Lee ${ }^{18}$ bahwa setiap tugas yang berhubungan dengan kemampuan motorik atau psikomotor memiliki dua tipe kesulitan yaitu kesulitan nominal berupa kompleksitas tugas dalam keadaan optimal dan kesulitan fungsional yang dipengaruhi oleh faktor eksternal.

Dalam penelitian ini menunjukkan bahwa tingkat kesulitan nominal terutama untuk mengukur kemampuan keterampilan/psikomotor caring mahasiswa karena termasuk keterampilan yang komplek, yang dipengaruhi oleh faktor kepribadian individu, emosional dan pengalaman. Sedangkan untuk tingkat kesulitan fungsional yang dipengaruhi oleh faktor eksternal juga berada pada tingkat yang sulit, dimana kemampuan psikomotor caring diterapkan secara langsung di ruang rawat inap rumah sakit dr. Doris Sylvanus Palangka Raya.

\section{Pengaruh Pelatihan Caring terhadap Kemampuan Afektif}

Tidak ada perbedaan signifikan antara kelompok intervensi dengan kelompok kontrol dalam hal kemampuan afektif caring Anderson dalam Sanjaya ${ }^{19}$ mengemukakan bahwa pelatihan atau strategi pembelajaran afektif berbeda dengan pelatihan atau pembelajaran kognitif dan psikomotor. Hal ini disebabkan karena afektif berhubungan dengan nilai (value) yang sulit untuk diukur karena menyangkut kesadaran individu yang tumbuh dari dalam dirinya. Kemampuan afektif mencakup watak perilaku seperti perasaan, minat, sikap, emosi, atau nilai. Ranah afektif menentukan keberhasilan belajar seseorang. Orang yang tidak memiliki minat terhadap apa yang dipelajarinya tentu sulit untuk mencapai keberhasilan belajar secara optimal. ${ }^{19}$ Ada dua metode yang dapat digunakan untuk mengukur ranah afektif, yaitu metode observasi dan metode laporan diri. ${ }^{19}$ Penggunaan metode observasi 
berdasarkan pada asumsi bahwa karateristik afektif dapat dilihat dari perilaku atau perbuatan yang ditampilkan dan/atau reaksi psikologi. Metode laporan diri berasumsi bahwa yang mengetahui keadaan afektif seseorang adalah dirinya sendiri. Namun hal ini menuntut kejujuran dalam mengungkap karakteristik afektif diri sendiri. Perilaku seseorang merupakan fungsi dari watak (kognitif, afektif, dan psikomotor) dan karakteristik lingkungan. ${ }^{19}$ Jadi dapat disimpulkan bahwa tindakan atau perbuatan seseorang ditentukan oleh watak dirinya dan kondisi lingkungan.Spitzberg ${ }^{20}$ juga mengemukakan hal yang sama dengan apa yang dikemukakan oleh Lewin, bahwa domain afektif dapat dipengaruhi perkembangan kognitif dan psikomotor. Hal ini juga diperkuat oleh teori conditioning (kebiasaan), yang menyatakan bahwa proses pembelajaran afektif atau sikap dilakukan melalui pembiasaan diri untuk melakukan sesuatu. ${ }^{15} \mathrm{Hal}$ lain yang juga dapat mempengaruhi pembelajaran afektif adalah modelling (role model).Modeling adalah proses meniru perilaku orang yang dihormati oleh si pembelajar. Dari apa yang dikemukakan para ahli tersebut diatas maka alasan yang menyebabkan tidak bermaknanya hasil analisis kemampuan afektif antara pos tes dan pre tes kemungkinan dipengaruhi oleh kemampuan kognitif dan psikomotor, dan karakteristik lingkungan saat perilaku atau perbuatan tersebut terjadi. Faktor lain adalah karakteristik lingkungan di ruang rawat inap rumah sakit dr. Doris Sylvanus, yang belum mendukung termasuk role model dalam menerapkan sikap caring saat memberikan asuhan keperawatan belum pada taraf yang maksimal.

\section{KESIMPULAN}

Pelatihan caring pada mahasiswa tidak menunjukkan perbedaan bermakna pada perilaku caring. Kemampuan kognitif dan afektif caring pada mahasiswa yang diberi pelatihan lebih tinggi dari pada mahasiswa yang tidak diberi pelatihan, tetapi secara statistik tidak bermakna. Kemampuan psikomotor pada mahasiswa yang diberi pelatihan caring lebih tinggi dari pada mahasiswa yang tidak diberi pelatihan caring dalam asuhan keperawatan, tetapi secara statistik tidak bermakna.
Perlu dilakukan penelitian lanjutan dengan metode pengukuran Time Series Design yaitu pengukuran observasi yang dilakukan berulang-ulang sebelum dan sesudah perlakuan. Dengan menggunakan serangkaian observasi (tes) agar mendapatkan validitas yang lebih tinggi.

\section{DAFTAR PUSTAKA}

1. Kozier, Erb's. Fundamental of nursing: concept, process and practice. 8 th ed. Pearson Prentice Hall; 2008.

2. Sitorus R. Model praktek keperawatan profesional di rumah sakit. Jakarta: Penerbit Buku Kedokteran; 2006.

3. Jean W. Theory of human caring [internet]; 2007 [cited 2009 Aug 4] Available from http:// www.nursing. Ucdenver.edu/faculty/ theory_caring.htm.

4. Purwaningsih. Pengaruh penerapan faktor karatif caring dalam asuhan keperawatan terhadap kinerja perawat pelaksana di ruang rawat inap perjan RS Persahabatan dan RS Fatmawati. [dissertation]. Jakarta (Indonesia): Universitas Indonesia; 2003.

5. Agustin I. Perilaku caring perawat dan hubungannya dengan kepuasan klien di instalasi rawat inap bedah dewasa RS Muhammad Hoesin Palembang [dissertation]. Jakarta (Indonesia): Universitas Indonesia; 2005.

6. Khademian Z, Vizeshfar F. Nursing students' perception of the importance of caring behaviors: Advanced nursing. 2008; 61(4):456-62.

7. Hsieh LJ, Kuo LC, Tseng FH. Application an evaluation of caring code in clinical nursing education: Nursing education. 2005; (4):177-84

8. Stuart GW, Laraia MT. Principle and practice of psychiatric nursing. 6th ed. St. Louis Mosby; 2001.

9. Chitty KK. Professional nursing concept and challenges. 2nd ed. Philadelphia: W.B. Saunders Company; 2003.

10. Patrick J. Training: Research and practical. London. Academic Press; 1991.

11. Taylor C. Fundamental of nursing the art and science of nursing care. Philadelphia: J.B. Lippincot; 1999.

12. Emilia O. Tip meningkatkan retensi memori. Jurnal pendidikan kedokteran dan profesi kesehatan Indonesia. 2008; 3(1): 1-8.

13. Irwanto, et.al. Psikologi umum Jakarta. Gramedia Pustaka Utama; 1994.

14. Yamin M. Paradigma pendidikan konstruktivistik. Jakarta: Gaung Persada Press; 2008. 
15. Arends RI. Learning to teach: belajar untuk mengajar. edisi 7 Volume I dan II. Yogyakarta: Penerbit Pustaka Pelajar; 2008.

16. Goetz PW. The new encyclopedi britanica. Vol 10, 15th. ed. Chicago: William Benton Publisher; 1981

17. Bond, Spurritt. Learning practical skill educating beginning practioners, challenges for health professional education. Butterworth-Heinemann; 1999.
18. Guadagnoli MA, Lee TD. Challenge point: Framework for conceptualizing the effects of various practice condition in motor learning motor behavior. 2005; 36 (2): 214-24.

19. Sanjaya W. Strategi pembelajaran: berorientansi standar proses pendidikan. Jakarta: Kencana Pre Media; 2008

20. Spitzberg BH. Communication competence as knowledge, skill and impression. Communication Education. 1983; 32: 323-30. 